\title{
Andragogy and Engagement in Online Learning: Tenets and Solutions
}

\author{
Barry Chametzky \\ Pennsylvania, United States \\ Email: barry@bluevine.net
}

Received 15 April 2014; revised 18 May 2014; accepted 1 June 2014

Copyright (C) 2014 by author and Scientific Research Publishing Inc.

This work is licensed under the Creative Commons Attribution International License (CC BY). http://creativecommons.org/licenses/by/4.0/

c) (7) Open Access

\begin{abstract}
In this paper, the author discusses two tenets of online learning: andragogy and learner engagement. What are the foundational principles of these educational practices? In light of the discussed foundational principles, the author examines various techniques which educators could use in order to help online learners succeed in the often-stressful environment. Ultimately, educators want learners to reach the pinnacle of Bloom's Taxonomy pyramid; by following the suggestions presented in this paper, educators will help learners accomplish this objective. Yet, more research is needed in this area. Therefore, the recommendation is for further study in the relationship between andragogy and the varied mesh of ideas associated with meaningfulness and engagement.
\end{abstract}

\section{Keywords}

\section{Andragogy, Online Learning, Engagement}

\section{Introduction}

Rear Admiral Grace Hopper once made a comment that forgiveness is easier to obtain than permission (Rolfe, 2012). Yet, with respect to Rear Admiral Hopper, if the behavior in question is done with good intention, has merit, and has possible benefit to people, organizations, or situations, asking for forgiveness should not be necessary (Rolfe, 2012). It might indeed seem strange that this paper on online learning began with a quote nearly 30 years ago from a military woman who was heavily involved in computers and computer coding. Yet, there is something that may be learned from this statement. In this paper, I hope to present two widely discussed (Bourke, 2014; Zhang \& Zheng, 2013) practices of online learning: andragogy and engagement. In the cases where employing those practices is not possible, I suggest ways that an educator could and should modify his or her lessons to help and accommodate learners. In such situations, to paraphrase Rear Admiral Hopper, in an attempt to correct the situation, it is easier to make decisions that are contrary to the accepted, standard practices rather 
than adhere to those practices and possibly fail.

\section{Literature Review}

With the increase of post-secondary online learning (Allen \& Seaman, 2010, 2013) in the United States and worldwide coupled with the desire of university administrators to increase revenues for their schools by reducing costs (Aslanian \& Clinefelter, 2012; Chau, 2010) and increasing enrollment (Mulvenon \& Robertson, 2014; Selingo, Carey, \& Pennington, 2013), it behooves educators and administrators to understand online learning and its associated concepts. With online learning, adult learners who are not able to be on campus but want to further their education will be able to learn at a time and place convenient for them (Aslanian \& Clinefelter, 2012). Because learners no longer need to travel to a campus to take a class, they are more able to learn anywhere and at anytime (Diaz, 2010; Islam, Rahman, Malib, Uddin, \& Bashir, 2014; Mallinson \& Krull, 2013).

\subsection{Andragogy}

One important element of online learning is andragogy. Though andragogy might be termed an adult learning theory (Bakar, 2013; Henschke, 2010) -Knowles (1980) referred to it as a "model of assumptions" (p. 43) elements of it are equally applicable to learners who are not adults. Regardless of how educational theorists define andragogy, five tenets are clearly present: 1) the self-management of learning, 2) the empowerment of learners leading to increased motivation, 3) the reliance on life experiences of learners to aid with their learning, 4) the objectives of learners for taking the course, and 5) the practical, real-world solutions to problems encountered in the course. Each of these elements will be briefly discussed in turn.

The first subcategory of andragogy deals with self-management of learning. In traditional classroom learning environments, students often sit passively and listen to the professor lecture from the front of the classroom. In an online environment, however, students must be more active in their knowledge acquisition. In addition, they must realize that the educator is no longer the single person who holds the knowledge. When students take responsibility for their own learning, they become active (Knowles, 1980) consumers in their learning; they become self-directed (Coole \& Watts, 2009; Knowles, 1975). Through self-direction, based on their individual needs (Prabjandee \& Inthachot, 2013), learners decide how fast or slow they will learn, when they wish to study, and in what direction their learning will proceed (Knowles, 1975, 1980).

Closely tied to the idea of self-management is the second idea of andragogy-empowerment leading to motivation. By being self-directed, learners feel empowered. Such a feeling, in turn, drives learners to learn more (Lebedev \& Fedoseyeva, 2009). Further, with this feeling of empowerment, learners are more motivated-especially in an online, asynchronous environment - to study anywhere and at anytime (Diaz, 2010).

The third subcategory of andragogy deals with life experiences. Learners have life experiences that prove highly valuable in a class based on andragogic principles. Such experiences form the figurative hooks onto which learners could place the new knowledge (Hedin, 2010; Mezirow, 2000). By creating these cognitive connections (McGrath, 2009) to previous knowledge, learners make the acquisition process easier. Further, because learning is self-directed in an andragogic classroom, these hooks and connections are vital to learner success; they aid the acquisition process, increase learner motivation, and help increase the desire to learn.

The relationship between the hooks that the educator illuminates to the student, the learners' motivation, and the desire to learn further is seen in Figure 1. The hooks lead the learner to feel that he or she can relate to the material more effortlessly thereby making the subject matter easier to internalize. Because this internalization is easier, learners perceive themselves to have a greater subject matter competence. A direct benefit of the increased confidence is the intensified enjoyment of the subject matter (Bennett \& Monds, 2008). These motiva-

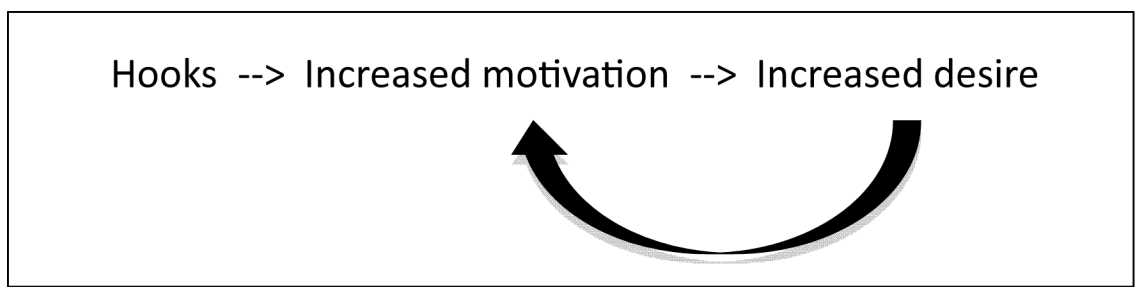

Figure 1. Relationship between educational hooks, learner motivation, and learner desire. 
tional indicators (Bennett \& Monds, 2008) propel learners to want to do the work, which, in turn, leads to the increase in "intrinsic motivation" (Evans, Hartman, \& Anderson, 2013: p. 48). When educators look at online learning through an andragogic lens, it is easy to see that a tight connection exists between "motivation and learning” (Savicevic, 2008: p. 364).

The fourth subcategory of andragogy deals with learner objectives. What does the learner hope to gain from taking the class at this particular time? The connection between learner objectives and motivation is strong (McGrath, 2009). If learners are motivated to acquire specific knowledge, they will do so. However, learners want and need to understand how the class information will benefit them (McGrath, 2009) in order to grow (Gutierrez, Baralt, \& Shuck, 2010). Without such knowledge, learners may not be ready to learn and internalize the necessary subject matter. In order to accomplish the goal of relating the subject matter to the lives of the learners, educators need to understand the scholastic objectives and motivational targets of the learners. Such understanding requires that learners and educator interact with each other (Chan, 2010) more than might generally be done in a traditional class where pedagogical principles govern the class.

The fifth and final element of andragogy deals with practical solutions to problems. The opportunity to address real-world situations in an andragogic learning environment is essential (Horsley, 2010; Zipp, Cahill, \& Clark, 2009). When learners realize that they need some specific knowledge acquired from solving a real-world issue, their level of motivation increases. In addition, when learners address real-world concerns (Wang \& Chen, 2009), their penchant for learning (Lebedev \& Fedoseyeva, 2009) the subject matter increases. Clearly, then, a strong tie exists between learner objectives and the solutions to real-world problems.

\subsection{Meaningfulness and Engagement}

The process of acquiring knowledge is multifaceted and multilayered. Several educational theorists (Gutierrez, Baralt, \& Shuck, 2010) have explained that numerous components comprise learning. One of these elements is interaction. Engagement happens either between course members or when a course member interacts with the course material. Ideally, both would happen simultaneously for maximum benefit (Chametzky, 2013a). The four-quadrant figure presented by Chametzky (2013a) demonstrates clearly how peer interaction and course material involvement work together to allow learners to develop deeper learning-acquisition of in-depth, meaningful learning built into pre-existing knowledge. Learners must interact with one another as well as with the course material in order for acquisition to be meaningful (Chametzky, 2013a). To interact solely with peers is to acquire the course information via a third-party; to interact solely with the textbook or course materials is to restrict the depth at which learning could and should take place.

In addition to the development of deeper learning, when learners are engaged with the subject material learners have a greater sense of satisfaction and development (Gutierrez, Baralt, \& Shuck, 2010). Anyone who might question this concept need only recall the Chinese proverb "Tell me and I forget. Teach me and I may remember. Involve me and I will understand” (Chametzky \& Shaw, 2009: p. 4) to understand being actively engaged in doing something aids in acquisition. Perišić (2012) summed the need for and requirement of interaction by opining that if engagement were not present, learning would not take place. While it might be debatable whether learning would occur, what is more certain is that engagement is a motivator for students to learn (Schullery, 2013); without it, learning is not able to have value (Wlodkowski, 2008).

It is precisely with the idea of value that the term meaningfulness is applicable and has significance. On the surface, the concept of meaningfulness seems like it might be easy to explain: if something is directly meaningful to an individual person (Ennis, 2013), it has, in a certain philosophical sense, relevance and worthwhileness, as the words may be thought of as being synonymous one with another (Metz, 2012). Such a definition is accurate but in online learning environment, the term meaningfulness has a deeper significance because of the intricate web of ideas and emotions that exists. In order to understand meaningfulness and why it is important, it is valuable to examine beliefs of several educational theorists.

According to Rothmann and Hamukang'andu (2013), meaningfulness is connected to self-fulfillment. Selffulfillment, in turn, comes in part from motivation and self-efficacy. In other words, if a person does not believe in his or her abilities to accomplish a given task, he or she might not be able to accomplish his or her ambitions. Such an absence or deficiency of self-fulfillment, in turn, causes a person to become less motivated. Educators in an online environment, therefore, must figure out how to make learners motivated in order to achieve selffulfillment and meaningfulness. 
Rothmann and Hamukang'andu (2013) described meaningfulness in terms of a psychological benefit in which people "experience that they are receiving a return on investment of the self in a currency of physical, emotional, and/or cognitive rewards" (p. 3). In an online environment where learners must work more independently and more actively than in a traditional environment, rewards - whether tangible, affective, or intellectual (Rothmann \& Hamukang’andu, 2013)—are needed and required for learners to maintain interest in the course material.

From a cognitive point of view, meaningful information has several benefits for students. When learners are engaged with the course materials and with peers, there exists a stronger vested interest in the acquisition of knowledge because of the additional connections that are made with the material in the students' personal lives. Additional connections are also made through scaffolding and via opportunities for deeper learning. When course material has relevance to learners, they function cognitively in the upper levels of Bloom's Taxonomy (Tsai, 2009). With meaningful learning, too, students are more likely to focus on the resolution of the problem or project (Pollock, 2013; Zhou, Yeung, Wang, Wang, \& Xiao, 2013) rather than on simply memorizing information.

\subsection{What If Andragogical Principles Are Not Present or Cannot Happen?}

For a learner to be able to function in an andragogic learning environment, four sub-doctrines must exist. These tenets form an acronym I call SEAR: Learners must be 1) Self-directed or Self-guided, 2) Encouraged, 3) Accustomed to learning in an andragogic manner, and 4) Ready to learn in an andragogic style. Sometimes, not everyone is ready (Knowles, 1984) to learn via these principles. In situations where learners do not have the skills required to learn via andragogic principles, Knowles (1980) recommended using pedagogic principles thereby allowing learners to rely on the educator to comprehend the fundamental information (McGrath, 2009). Then, at a later date, when the learners are sufficiently prepared, learning via andragogic tenets could happen. Knowles (1980) understood that the principles of andragogy must enable learning rather than form a barrier (Zhang \& Zheng, 2013) thereby preventing or inhibiting learning.

How might an educator help students become more aware from an andragogic perspective? I offer three ways exist to help learners become sufficiently prepared to function in an andragogic educational environment. The first element is to ensure that the primary needs of learners are satisfactorily addressed à la Maslow's Hierarchy of Needs (Millheim, 2012). For example, good illustrations of primary needs of learners are safety (Gutierrez, Baralt, \& Shuck, 2010) and resource availability. Resource availability (Illeris, 2003; Knowles, 1980) and personal safety must be ensured before learners are able to study and engage in the subject matter.

A second way to prepare learners for an andragogic environment would be to have educators ask them what topics are of interest to them. Then, armed with that knowledge, educators should allow learners to guide their studies in that direction. By allowing learners to take a more active role in their education by choosing specific areas of study, educators are empowering students. The ideas of empowerment, self-management of learning, and, motivation are intertwined so any opportunity an educator has to help learners develop in these areas should be taken. Since learners may not be accustomed to being empowered in their education (Stroud, 2013)—perhaps because of different cultural experiences (Chan, 2010)—it is advisable that the process of empowerment be done gradually.

A third and final way to prepare learners for a learning environment based on andragogic principles would be to develop the course plan around real-world problems and their practical solutions. While it might not be practical to redesign an entire course around authentic problem-based learning and their solutions, it should be possible, and relatively easy, for educators to structure units or activities with this objective in mind. I offer here three brief yet diverse examples of real-world problems and solutions.

The first example is in the area of world languages. In a lower-level language class, an educator might inform the students that each of them will be on a job interview at the end of the semester and must be able to talk about themselves in the target (that is, foreign) language. Immediately following the initial greeting, what questions might be asked by prospective employers during a job interview? And, how might learners answer those questions? Because most job interviews begin with the casual "Tell me about yourself" type request, learners have an opportunity to see the real-world usefulness when they talk about their likes, dislikes, education, or family members. A second task might come from an accounting class where learners must balance a budget and thus discover the necessary elements to accomplish the task successfully. Finally, a third example comes from a mathematics class where you, the student, are going to meet an old friend whom you have not seen in many years. 
The meeting location will be at a nearby town 45 miles away from your home. Your friend lives 200 miles away and will be taking a train that travels at 55 miles per hour. You will be driving your car on roads where the speed limit is 65 miles per hour. At what time will you need to leave your home in order to meet your friend at the train station?

In each of these scenarios, educators employ real-world situations based on specific tasks (Chowdhury, 2014). The objective of learners is to determine what information and knowledge are needed to solve the real-world problems. When learners see the real-world practicality of these tasks and solutions-especially if there is relevance to their lives- the level of motivation and interaction with the course material increases.

\subsection{How Could Meaningfulness and Engagement Be Increased?}

Learner engagement with the course material depends on several factors, not the least of which are motivation and meaningfulness. With minimum engagement_as in solely reading the course textbook without peer interaction-motivation would possibly be reduced. I say possibly because other variables may come into play that are heretofore unknown and are outside the scope of this paper. In order to have maximum student engagement with the subject material and with peers, educators must make the material relevant and personally meaningful to the learners; only then will their motivation to participate increase (Ray, Faure, \& Kelle, 2013).

In order to increase engagement, and by extension meaningfulness, an educator would need to make certain modifications to several components of the class. One way to increase meaningfulness is through relevance of the course materials. If learners are able to relate the new material to some aspect of their lives, relevance and meaningfulness will be increased. Similarly, if the course material has personal relevance and importance to learners, learners will acquire the information more easily than if it had no direct benefit to their lives (Kazempour, 2009). Conversely, when material is not sufficiently meaningful to learners, they may easily lose interest or exhibit only surface learning_knowledge useful and meant only for the course (Starr-Glass, 2013)—instead of deeper learning.

Another way to increase engagement and thereby increasing meaningfulness is with learner-centered work such as collaborative activities. With these types of activities, it is the responsibility of the learners to determine how the learning will occur. In addition, it is the responsibility of individual learners how each could help the group members acquire the necessary knowledge (Hannafin, Hannafin, \& Gabbitas, 2009) in order to complete the exercise successfully. One outcome of this type of activity is the opportunity students have to share different perspectives of the material with one another. By exchanging ideas as they progress through the exercise, learners are able to acquire the material more thoroughly (Kaifi, Mujtaba, \& Williams, 2009). With a deeper understanding of the course material, learners feel that it (the subject matter) has a greater meaningfulness for them.

Sometimes, however, the idea of participating in a group learning or collaborative experience may cause increased anxiety. Educational researchers (Chametzky, 2013b; Kiliç-Çakmak, Karatas, \& Ocak, 2009) know that experience and expectation must be aligned with each other or levels of anxiety will increase. Should anxiety increase in a learner, behavioral disconnect would ensue.

In such situations, it would be important for educators to explain that grades for the project would be done differently from the way students were perhaps accustomed. For a group collaborative assignment, two sets of grades (Palloff \& Pratt, 2009) would be given. Peer group members would provide the first grade. The basis for this grade would be the effort each person in the group made on the assignment. The second grade would be a group grade. As with any assessment, it is the prerogative of the educator to use his or her "veto power [in case...] discrepancies [exist] between individual and group assessments” (Palloff \& Pratt, 2009: p. 116). The benefit to having a two-grade evaluation is that if one member of the group were not performing to his or her ability, the grades of the other members would not be affected. From an engagement perspective, such an assessment should lower the anxiety levels of learners and increase engagement.

Meaningfulness may be created or enhanced in an online environment in several ways. An educator might be to ask students why they feel that a particular topic or unit is important to them. Such a question serves two purposes. First, such a question allows students to recall previous learning experiences and create a hook about which I spoke earlier in this paper. This question has its roots in the Madeline Hunter lesson plan model in which each lesson begins with an anticipatory set (Han, Halim, Abdullah, \& Shariffuddin, 2013).

Second, should the material not appear useful to one or more learners, such a question affords them the opportunity to hypothesize about why the topic or, on a larger scale, the course might be useful thereby developing 
higher-order thinking (Bloom, 1984). By obtaining an answer to this question, educators might be able to ascertain any external motivational factors that might affect learner acquisition. If the topic or the course were truly meaningless to a student, he or she would not be in the course. Thus, some level of interest must exist. It is the responsibility of the educator to develop this interest further.

From a different perspective, meaningfulness can occur only when other conditions have been addressed similar to Maslow's (1967) Hierarchy of Needs. In an online environment, these conditions refer to the availability of course materials and technological tools. When the materials in a course are readily available to learners and when the safety of learners is ensured, they are able to focus on the meaningfulness of the task at hand (Gutierrez, Baralt, \& Shuck, 2010). Conversely, if the materials or technological tools are not available to learners and the activity that they are required to cause their affective filter to be raised (Chametzky, 2013b), learners can neither focus on the meaningfulness of a task nor its successful completion.

To accomplish the task of ensuring that the conditions have been addressed, educators may do several things. First, an educator should be proactive and have the course materials read when the course starts, presuming that the entire course will be available to the students from the first day of class. Course materials include but are not limited to having working hyperlinks and all ancillary information (Word documents, PowerPoint presentations, videos, and so on) available. Second, any technological issues must be resolved, to the extent possible, before the class begins. Then, when the class starts, learners should have a chance to explore all (or as many) technological tools as possible via different types of non-graded activities. By having the activities non-graded, educators are removing any anxiety. Thus, learners are able to explore without the fear of doing poorly. Finally, educators must spell out the requirements and grading procedures. To say that an assignment is worth 10 points is insufficient in an online venue. By creating a rubric (Palloff \& Pratt, 2009) with the exact breakdown of the points, educators are helping students to know exactly what is expected of them and exactly how they will assessed. Again, it is crucial to ensure that learner experience and expectation (Kiliç-Çakmak, Karatas, \& Ocak, 2009) are aligned with each other; rubrics may help educators achieve this objective.

\section{Conclusion}

Proper teaching requires that educators know their students and what they are capable of accomplishing. Not all the time should or could educators address the principles of andragogy in a learning environment. When learners engage with the material and with each other under the guidance and tutelage of a competent online or traditional educator, students go beyond memorizing information to regurgitate on a test. Learning becomes more comprehensive because of the interaction and communication that exist among course members. Especially in an online environment, interactive peer dialogue is vital to the success of the course and to overall student satisfaction (Kuo, Walker, Belland, Schroder, \& Kuo, 2014).

Educators want all learners to be at the pinnacle of Bloom's (1984) Taxonomy pyramid. When educators have students take responsibility for their own learning, engage actively with the course materials, and use collaborative activities to allow peer interaction, more opportunities for learners exist to reach the pinnacle of the pyramid, provided the educational and social needs found in the lower levels have been adequately addressed (Cruz, 2013). Through this interaction and dialogue, learners develop higher-order cognitive skills (Bloom, 1984), practice thinking critically, and grow as individuals. Ultimately, this development is the real goal of learning.

\section{References}

Allen, I., \& Seaman, J. (2010). Class Differences: Online Education in the United States, 2010. Needham, MA: The Sloan Consortium, 1-26. http://sloanconsortium.org/publications/survey/class_differences

Allen, I., \& Seaman, J. (2013). Changing Course: Ten Years of Tracking Online Education in the United States, 2010. Needham, MA: The Sloan Consortium, 1-26. http://sloanconsortium.org/publications/survey/class_differences

Aslanian, C., \& Clinefelter, D. (2012). Online College Students 2012: Comprehensive Data on Demands and Preferences. Louisville, KY: The Learning House, Inc.

Bakar, K. (2013). Meaning of Andragogy. Al-Madinah Language Studies, 2. http://scholar.mediu.edu.my/index.php/LANGUM/article/view/13758/13327

Bennett, C., \& Monds, K. (2008). Online Courses: The Real Challenge Is “motivation”. College Teaching Methods \& Styles Journal, 4, 1-6. http://journals.cluteonline.com

Bloom, B. (1984).Taxonomy of Educational Objectives, Handbook I: The Cognitive Domain. White Plains, NY: Longman. 
Bourke, B. (2014). Adult Millennials: Conceptualizing a Student Subpopulation with Implications for Online Teaching and Learning. In J. Keengwe, \& G. L. Schnellert (Eds.), Cross-Cultural Online Learning in Higher Education and Corporate Training (pp. 62-78). http://dx.doi.org/10.4018/978-1-4666-5023-7.ch003

Chametzky, B., \& Shaw, M. (2009). Activities to Integrate Internet Usage in College Foreign Language Classes. Ubiquitous Learning: An International Journal, 2, 13-20. http://ijq.cgpublisher.com/product/pub.186/prod.48

Chametzky, B. (2013a). What Is Involved in Meaningful E-Learning? Journal of Interdisciplinary Collaboration, 1, 41-59.

Chametzky, B. (2013b). Offsetting the Affective Filter and Online Foreign Language Learners. http://www.igi-global.com/open-access/paper/offsetting-affective-filter-classic-grounded/7

Chan, S. (2010). Applications of Andragogy in Multi-Disciplined Teaching and Learning. Journal of Adult Education, 39, 25-35. https://www.mpaea.org/docs/pdf/Vol39No22010.pdf

Chau, P. (2010). Online Higher Education Commodity. Journal of Computing in Higher Education, 22, 177-191. http://dx.doi.org/10.1007/s12528-010-9039-y

Chowdhury, M. (2014). The Task-Based Learning Framework and Its Implications in Language Learning and Teaching. Journal of Education and Practice, 5, 111-117. http://iiste.org/Journals/index.php/JEP/article/view/10646

Coole, H., \& Watts, M. (2009). Communal E-Learning Styles in the Online Classroom. Research in Education, 82, 13-27. http://dx.doi.org/10.7227/RIE.82.2

Cruz, A. (2013). Educational Technology for Teaching and Learning. Cuadernos de Educación y Desarrollo, 32. http://www.eumed.net/rev/ced/

Diaz, S. (2010). Meet Cisco Cius: Android Tablet for Workers, Students. Watch Out, iPad? http://www.zdnet.com/blog/btl/meet-cisco-cius-android-tablet-for-workers-students-watch-out-ipad/36387

Ennis, C. (2013). Implementing Meaningful, Educative Curricula, and Assessments in Complex School Environments. Sport, Education and Society, 18, 115-120. http://dx.doi.org/10.1080/13573322.2012.707978

Evans, K., Hartman, C., \& Anderson, D. (2013). “It’s More than a Class”: Leisure Education's Influence on College Student Engagement. Innovative Higher Education, 38, 45-58. http://dx.doi.org/10.1007/s10755-012-9223-2

Gutierrez, C., Baralt, S., \& Shuck, B. (2010). The Integrated Process of Engagement in Adult Learning. In M. S. Plakhotnik, S. M. Nielsen, \& D. M. Pane (Eds.), Proceedings of the 9th Annual College of Education \& GSN Research Conference (pp. 33-39). Miami: Florida International University. http://coeweb.fiu.edu/research_conference/

Han, O., Halim, N., Abdullah, Z., \& Shariffuddin, R. (2013). Application of Madeline Hunter Model in Mathematics Learning Courseware. 2013 International Conference on Informatics and Creative Multimedia (ICICM), Kuala Lumpur, 4-6 September 2013, 76-80. http://dx.doi.org/10.1109/ICICM.2013.61

Hannafin, M., Hannafin, K., \& Gabbitas, B. (2009). Re-Examining Cognition during Student-Centered, Web-Based Learning. Educational Technology Research \& Development, 57, 767-785. http://dx.doi.org/10.1007/s11423-009-9117-X

Hedin, N. (2010). Experiential Learning: Theory and Challenges. Christian Education Journal, 7, 107-117. http://journals.biola.edu/cej

Henschke, J. (2010). An International Capsule of a Perspective of the History and Philosophy of Andragogy. Andragoške Studije, 2, 9-34. http://www.as.edu.rs/static/pdf/Andragoske\%20studije\%202010-2.pdf\#page=9

Horsley, T. L. (2010). Innovative Learning Activity. Journal of Nursing Education, 49, 363-365. http://dx.doi.org/10.3928/01484834-20090521-02

Illeris, K. (2003). Workplace Learning and Learning Theory. Journal of Workplace Learning, 15, 167-178. http://dx.doi.org/10.1108/13665620310474615

Islam, T., Rahman, S., Malib, S., Uddin, K., \& Bashir, G. (2014). Design and Implementation of Web Based Collaborative Learning Model for ICT Course of College Student [sic] in Bangladesh. International Journal of Computer Science and Mobile Computing, 3, 393-400. www.ijcsmc.com

Kaifi, B., Mujtaba, B., \& Williams, A. (2009). Online College Education for Computer-Savvy Students: A Study of Perceptions and Needs. Journal of College Teaching \& Learning, 6, 1-16. http://journals.cluteonline.com/index.php/TLC

Kazempour, M. (2009). Impact of Inquiry-Based Professional Development on Core Conceptions and Teaching Practices: A Case Study. Science Educator, 18, 56-68. http://www.nsela.org/index.php?option=com content\&view=category\&id=51\&Itemid=85

Kiliç-Çakmak, E., Karatas, S., \& Ocak, M. (2009). An Analysis of Factors Affecting Community College Students’ Expectations One-Learning [sic]. Quarterly Review of Distance Education, 10, 351-363.

http://www.infoagepub.com/quarterly-review-of-distance-education.html

Knowles, M. (1975). Self-Directed Learning: A Guide for Learners and Teachers. Chicago, IL: Follett Publishing Company.

Knowles, M. (1980). The Modern Practice of Adult Education: From Pedagogy to Andragogy. Chicago, IL: Follett Publishing Company. 
Knowles, M. (1984). Introduction: The Art and Science of Helping Adults Learn. In M. S. Knowles (Ed.), Andragogy in Action: Applying Modern Principles of Adult Learning (pp. 1-21). San Francisco, CA: Jossey-Bass.

Kuo, Y., Walker, A., Belland, B., Schroder, K., \& Kuo, Y. (2014). A Case Study of Integrating Interwise: Interaction, Internet Self-Efficacy, and Satisfaction in Synchronous Online Learning Environments. International Review of Research in Open and Distance Learning, 15. http://www.irrodl.org/index.php/irrodl/article/view/1664/2768

Lebedev, A., \& Fedoseyeva, T. (2009). Principles of Learning and Interrelation of Learning and Teaching in Present-Day Andragogy. Vestnyk DonNACEA, 3, 107-112. http://www.dgasa.dn.ua/inform.php?lng=e\&pid=188\&art=198

Mallinson, B., \& Krull, G. (2013). Building Academic Staff Capacity to Support Online Learning in Developing Countries. Journal of Asynchronous Learning Networks, 17, 63-72.

http://sc-d7.sloan-c-support.org/sites/default/files/articles/downloads/7\%20BUILDING\%20ACADEMIC\%20STAFF\%20 CAPACITY_0.pdf

Maslow, A. (1967). A Theory of Metamotivation: The Biological Rooting of the Value-Life. Journal of Humanistic Psychology, 7, 93-127. http://dx.doi.org/10.1177/002216786700700201

McGrath, V. (2009). Reviewing the Evidence on How Adult Students Learn: An Examination of Knowles’ Model of Andragogy. The Irish Journal of Adult and Community Education 2009 [sic], 99-110. http://www.aontas.com

Metz, T. (2012). The Meaningful and the Worthwhile: Clarifying the Relationships. The Philosophical Forum, 43, 435-448. http://dx.doi.org/10.1111/j.1467-9191.2012.00436.x

Mezirow, J. (2000). Learning to Think like an Adult. Core Concepts of Transformation Theory. In J. Mezirow, \& Associates (Eds.), Learning as Transformation. Critical Perspectives on a Theory in Progress (pp. 3-33). San Francisco, CA: Jossey-Bass.

Millheim, K. (2012). Toward a Better Experience: Examining Student Needs in the Online Classroom through Maslow’s Hierarchy of Needs Model. MERLOT Journal of Online Learning and Teaching, 8, 159-171. http://jolt.merlot.org/index.html

Mulvenon, S., \& Robinson, D. (2014). The Paradox of Increasing both Enrollment and Graduation Rates: Acknowledging Elephants in the Ivory Tower. International Journal of Higher Education, 3, 66-70. http://dx.doi.org/10.5430/ijhe.v3n1p66

Palloff, R., \& Pratt, K. (2009). Assessing the Online Learner: Resources and Strategies for Faculty. San Francisco, CA: Jossey-Bass.

Perišić, V. (2012). Zappers in Teaching Mathematics. The First Annual Conference on the Aiming for Excellence in STEM Learning and Teaching, London: Imperial College. http://perisic.com/vesna/STEM_con_paper_10_03_12.pdf

Pollock, D. (2013). Designing and Teaching Online Courses. http://fsweb.bainbridge.edu/QEP/Docs/DesigningandTeachingOnlineCourses.pdf

Prabjandee, D., \& Inthachot, M. (2013). Self-Directed Learning Readiness of College Students in Thailand. Journal of Educational Research and Innovation, 2, 1-11. http://scholarlyexchange.org/ojs/index.php/JERI

Ray, B., Faure, C., \& Kelle, F. (2013). Using Social Impact Games (SIGS) to Support Constructivist Learning: Creating a Foundation for Effective Use in the Secondary Social Studies Education. American Secondary Education, 41, 60-70. http://www.ashland.edu/coe/about-college/american-secondary-education-journal

Rolfe, G. (2012). Fast Food for Thought: How to Survive and Thrive in the Corporate University. Nurse Education Today, 1-5. http://dx.doi.org/10.1016/j.nedt.2012.03.020

Rothmann, S., \& Hamukang’andu, L. (2013). Callings, Work Role Fit, Psychological Meaningfulness and Work Engagement among Teachers in Zambia. South African Journal of Education, 33, 1-16. http://www.sajournalofeducation.co.za

Savicevic, D. (2008). Convergence or Divergence of Ideas on Andragogy in Different Countries. International Journal of Lifelong Education, 27, 360-378. http://dx.doi.org/10.1080/02601370802051504

Schullery, N. (2013). Workplace Engagement and Generational Differences in Values. Business and Professional Communication Quarterly, 76, 252-265. http://dx.doi.org/10.1177/1080569913476543

Selingo, J., Carey, K., \& Pennington, H. (2013). The Next Generation University. http://www.smarthighered.com/wp-content/uploads/2013/05/THE-NEXT-GENERATION-UNIVERSITY.pdf

Starr-Glass, D. (2013). Learning through Learning: Experiential Resonance in an Online Management Course. International Journal of Management, Knowledge and Learning, 2, 65-82. www.issbs.si/press/ISSN/2232-5697/2_65-82.pdf

Stroud, R. (2013). Task-Based Learning Challenges in High Schools: What Makes Students Accept or Reject Tasks? The Language Teacher, 37, 21-28. http://jalt-publications.org/tlt

Tsai, M. J. (2009). The Model of Strategic E-Learning: Understanding and Evaluating Student E-Learning from Metacognitive [sic] Perspectives. Journal of Educational Technology \& Society, 12, 34-48. http://www.ifets.info

Wlodkowski, R. J. (2008). Enhancing Adult Motivation to Learn: A Comprehensive Guide for Teaching All Adults. San Francisco, CA: Jossey-Bass. 
Wang, Y., \& Chen, N. S. (2009). Criteria for Evaluating Synchronous Learning Management Systems: Arguments from the Distance Language Classroom. Computer Assisted Language Learning, 22, 1-18. http://dx.doi.org/10.1080/09588220802613773

Zhang, C., \& Zheng, G. (2013). Supporting Adult Learning: Enablers, Barriers, and Services. Proceedings SIGITE'13 Proceedings of the 14th Annual ACM SIGITE Conference on Information Technology Education, 151-152. http://dx.doi.org/10.1145/2512276.2512323

Zhou, S., Yeung, Y., Wang, Y., Wang, X., \& Xiao, H. (2013). Integrating Effective Pedagogies in Science Education with a Design of Alternative Experiments on Electromagnetics. Eurasia Journal of Mathematics, Science \& Technology Education, 10, 13-21. http://www.ejmste.com

Zipp, G., Cahill, T., \& Clark, M. (2009). The Role of Collaborative Scholarship in the Mentorship of Doctoral Students. Journal of College Teaching and Learning, 6, 29-35. http://journals.cluteonline.com/index.php/TLC 
Scientific Research Publishing (SCIRP) is one of the largest Open Access journal publishers. It is currently publishing more than 200 open access, online, peer-reviewed journals covering a wide range of academic disciplines. SCIRP serves the worldwide academic communities and contributes to the progress and application of science with its publication.

Other selected journals from SCIRP are listed as below. Submit your manuscript to us via either submit@scirp.org or Online Submission Portal.
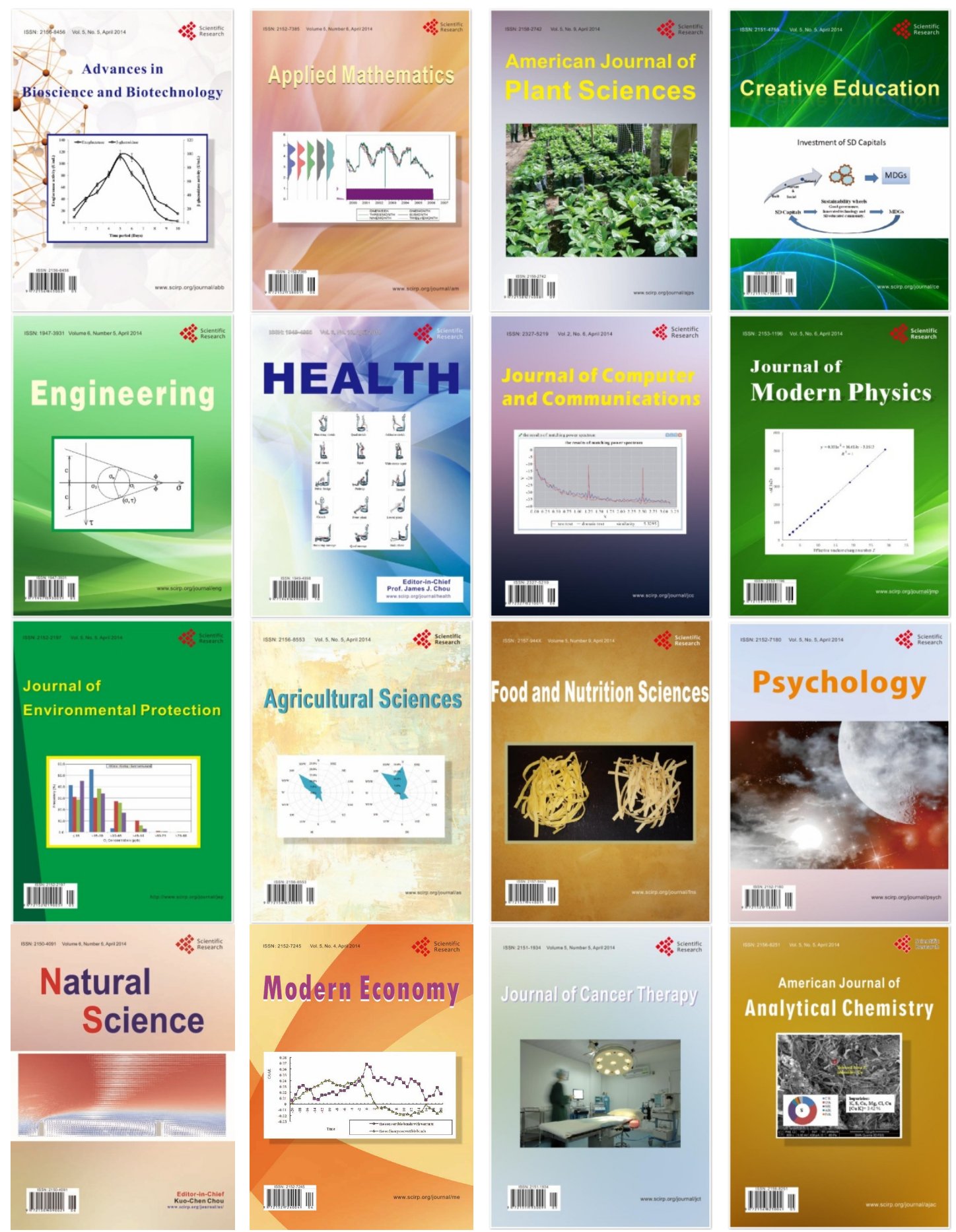